\title{
Are Large Shareholders Conducting Influential Monitoring in Emerging Markets? An Investigation into the Impact of Large Shareholders on Dividend Decisions: The Case of Kuwait
}

\author{
Duha Al-Kuwari \\ The Middle East Centre, London School of Economics and Politics \\ 10.01, Houghton Street, London WC2A 2AE, UK \\ E-mail: D.AL-Kuwari@lse.ac.uk
}

Received: August 13, 2012

Accepted: August 31, $2012 \quad$ Online Published: September 12, 2012

doi:10.5430/rwe.v3n2p52

URL: http://dx.doi.org/10.5430/rwe.v3n2p52

\begin{abstract}
This paper examines the relationship between large shareholders and dividend payout decisions based on agency theory and investigates whether large shareholders are monitoring effectively. The study uses a panel dataset of 37 non-financial firms listed on the Kuwait Stock Exchange as an emerging market between 1999 and 2003. Random-effects probit models are used to examine the impact of large shareholders, firm size, free cash flows, investment opportunity, business risk, and firm profitability on the dividend amounts firms paid. Large shareholders are disaggregated into three types - institutions, governments, and large individual shareholders - to determine if they influence the dividend paid. The results suggest that government is the only large shareholder that plays a significant monitoring role on dividend decisions. Furthermore, the results show that government ownership and firm profitability increase the probability of paying dividends, while the leverage ratio decreases the probability. Overall, the findings indicate that companies listed on the Kuwait Stock Exchange pay dividends to reduce agency conflict and avoid exploiting minority shareholders.
\end{abstract}

Keywords: Agency theory, Dividend payout decision, Emerging market, Large shareholders, Panel data, Random-effects probit model

\section{Introduction}

In 1932, Berle and Means provide a foundation for the theory of modern organization that is based on a wide dispersion of ownership structures in corporations, while many recent studies show an increase in concentrated ownership by large shareholders in corporations (e.g., Truong and Heaney, 2007; Gugler and Yurtoglu, 2003; Claessens et al., 2000; Faccio et al., 2001; La Porta, 1999; Morck et al., 1988; Shleifer and Vishny, 1986; Demsetz and Lehn, 1985). Chen and Sinha (2011), Claessens et al. (2002), Shleifer and Vishny (1997), and Zeckhauser and Pound (1990) argue that theoretical and empirical studies highlight contrasting explanations for the influence of large shareholders; that is, on the one hand, large shareholders, as a distinct group of shareholders, hold a block of voting power. Therefore, their investments are sensitive to firm decisions and have sturdy inducement to monitor management performance and ensure that a firm's value is enhanced. Thus, large shareholders might be able to solve the vital problem of modern organization theory - the problem outside shareholders have in monitoring management. On the other hand, large shareholder behaviors might be motivated by the possibility of enjoying the private benefits of control at the expense of outside shareholders. Truong and Heaney (2007) add that, while large shareholders exercise pressure on a firm to implement dividend payout policies as instruments to minimize private benefits for firm management, large shareholders still have the strength to impose a dividend policy that enhances private benefits for themselves at the expense of minority shareholders.

However, Holderness (2003) argues that there are some gaps in the literature review of ownership structure, and further studies are required to justify the effects of large shareholder behaviors on a firm's polices and decisions. In line with the Holderness (2003) argument, most previous studies are based on developed markets, while little attention is paid to the impact of large shareholders on dividend policies and monitoring problem in emerging markets. This field is currently not well established in the literature, in which emerging markets differ significantly from developed markets with regard to their characteristics, size, and efficiency. 
This study investigates the extent to which large shareholders affect dividend decisions in emerging markets. In particular, this study examines firms listed on the Kuwait Stock Exchange (KSE) as an example of the economy of the Gulf Cooperation Council (GCC) countries (Note 1). The study contributes to existing knowledge in several ways. It is one of very few studies to examine non-financial firms in Kuwait, which, together with other GCC states, represents an important region in the world that provides a framework for the stability of oil and gas supplies worldwide. These countries own approximately $45 \%$ of the world's crude oil reserves and around $15 \%$ of its natural gas reserves. Furthermore, they account for nearly $15 \%$ of the international production of crude oil; their crude oil exports account for around 20\% of total international exports (Note 2) (IMF, 2012; Al-Kuwari 2012; Al-Ibrahim, 2004).

Furthermore, Kuwait, together with other GCC countries, has certain unique characteristics that make the study appropriate in terms of policy recommendations for the GCC countries and other emerging countries. First, the Kuwait environment is unique in that taxes are not paid on dividends or capital gains. This leads investors to these particular countries, favoring large dividend payouts. Furthermore, the Kuwait government owns a significant portion of the shares of the firms listed on the KSE. One advantage of government participation is that the government is usually a large shareholder, so liquidity and fundraising to finance investment projects are unlikely to be problems (Gul, 1999). However, the stock exchanges of the GCC countries, as in other emerging markets, are more volatile and entail a certain degree of information asymmetry in addition to the expectation of high agency costs.

Due to Kuwait's unique characteristics, there is considerable interest in analyzing the impact of large shareholders' behaviors on the dividend decisions of companies listed on the KSE. To examine this impact, the present study will use a panel dataset of companies listed on the KSE between 1999 and 2003 as an example of an emerging market. Exploratory data analysis reveals that one firm paid dividends in one year and did not pay dividends in other years. Some firms did not pay dividends at all during the study period, while others always paid dividends. This, then, raises an interesting research question: Do large shareholders influence the decision of whether or not to pay a dividend, and do different types of large shareholders affect the decision differently? To investigate the research questions, this study develops nine research predictions to discuss the factors that affect dividend payment decisions. The results, based on probit specifications, propose that different large shareholders might be affected differently when making dividend decisions. Furthermore, the study shows that the government is the only significantly large shareholder among other large shareholders that affects the probability that a company will pay dividends. In addition, the study shows that larger companies, which are more profitable and have low leverage, are also more likely to pay dividends. In summary, the findings show that the government is the only type of large shareholder that affects the dividend decision; the result also supports the explanation of agency costs of dividend policies.

The remainder of the paper is organized as follows: Section 2 reviews previous papers and develops the research hypotheses while Section 3 provides background information about the corporate ownership structures of the GCC states. Section 4 presents the formal model, study prediction, and variables employed. Section 5 describes the data, and Section 6 presents a random-effects probit model to investigate the research question and the relevant predictions. Finally, Section 7 reports the results and the associated discussions. The paper ends with a summary of the findings and conclusions.

\section{Literature Review and Research Hypotheses}

In the context of modern organizational theory, firms can be viewed as encompassing principles (shareholders) and agents (managers). Although Miller and Modigliani (1961) presuppose that, in an efficient market, agents and principals have the same goal of maximizing shareholder wealth; this is not valid in the real world. In the real world, managers, who are authorized by shareholders to administer firm assets, may tend to take advantage of their authority to divert firm assets to themselves through outright theft, excessive salaries, or sales of assets at prices favorable to themselves, resulting in high agency costs (La Porta et al., 2000).

The payment of dividends is considered a workable instrument to increase monitoring of managers' performance and diminish management agency costs. Easterbrook (1984) suggests that, as firms adapt large dividend payout policies - assuming that the firm is engaging in current and future premeditated investment projects - it is obliged to depend on capital markets more often. Capital market regulation works to monitor the behaviors of managers, since investment professionals strictly examine firms when new securities are offered. Thus, dividend payments increase management scrutiny by outsiders, and hence force managers to disclose new information and reduce agency costs in order to secure requisite funds. 
In his free cash flow theory, Jensen (1986) proposes that the commitment to pay dividends eliminates free cash flows, thereby squeezing managers' accessibility to overinvestment in projects that promote personal interest. Rozeff (1982), one of the first to exploit the impact of inside (controlling) shareholders, presents a model that underpins agency conflict theories and finds that firms increase dividend payout ratios as controlling shareholders decrease and/or the dispersement of outside shareholders increases.

While Berle and Means (1932) deduce that ownership structure is distributed extensively among small shareholders who typically have little incentive to monitor management, La Porta et al. (1999) refute this assumption in their examination of a developed and developing market. Beachet and Mayer (2000) examine EU markets; Claessens et al. (2000) cover nine East Asian markets; and Truong and Heaney (2007) examine 37 companies around the world, indicating that corporations with large ownership concentrations and large shareholders exist. Shleifer and Vishny (1986) and Grossman and Hart (1980) indicate that the existence of large shareholders could play a role in effectively monitoring the activities of firms' managers and inside shareholders, thus alleviating the free-rider problem associated with dispersed small shareholders. They explain that large shareholders have more inducements and efforts than small shareholders to carry the cost of monitoring since the consequences of and returns from monitoring surpass the cost. Grinstein and Michaely (2005) and Redding (1997) explain that the largest shareholders have a strong incentive to adopt and enhance means to advance their role of effectively monitoring the activities of firm managers.

Claessens et al. (2002) imply a positive relationship between dividends and large shareholders. They attribute this positive relationship to the fact that, as the largest shareholders are controlling shareholders, they can choose to pay high dividends in order to minimize extraordinary monitoring costs. Furthermore, Claessens et al. (2002) indicate that large shareholders adopt large dividend payouts as a mechanism of maintaining firm value and enhancing the firm's reputation for not expropriating the wealth of its minority shareholders. Truong and Heaney (2007) hypothesize that firms adopt a positive relationship between large shareholders and dividend payout decisions in order to enhance monitoring of manager performances. These explanations are supported by Zeckhauser and Pound (1990) and Eckbo and Verma (1994). Zeckhauser and Pound (1990) suggest that, like large shareholders, institutions are unlikely to monitor firm managers directly. Therefore, institutions might utilize their vetoing power to induce firms to make dividend decisions. By buying dividends, firms will be compelled to externalize fund monitoring; thus agency conflicts will be minimized. This explanation is in line with Eckbo and Verma (1994), who state that institutional shareholders can choose cash flows to pay dividends intended to minimize the cost of free cash flows. Short et al. (2002) also find a direct relationship between institutions as large shareholders and dividend policy when they test a sample of 211 firms listed on the London Stock Exchange. However, they consider the existence of tax clientele, showing that, due to comparative tax advantages, some institutions pay higher dividends relative to individual investors. As institutional investors are taxed lesser amounts, firms tend to pay higher dividends. This result is supported by Khan (2006), who examines 330 large public firms in the UK. Shleifer and Vishny (1986) and Moh'd et al. (1995) indicate that firms that have institutions as large shareholders pay higher dividends with the aim of attracting large shareholders. Gugler (2003) argues that government involvement can create a complex agency conflict environment. That is, agency problems may emerge between citizens and the government that may not serve the best interests of the citizens it represents. Conflict might also materialize between the government and other managers, where managers often seek their personal interests from the resources available to a firm, allowing them to increase their salaries and accrue benefits at the expense of other shareholders. Therefore, governments, as large shareholders, might employ dividend payout decisions to reduce the complex setting of agency problems.

According to the above, this paper hypothesizes the following:

H1: Large shareholders positively affect dividend payout decisions.

However, Gugler and Yurtoglu (2003) argue that, although large shareholders can monitor manager performances, they also have the power to expropriate small outside shareholders. Similarly, Pergola and Verreault (2009), Shleifer and Vishny (1997), and Demsetz and Lehn (1985) explain that, like controlling shareholders, large shareholders might use their authority to act in pursuit of their private benefits, mostly at the expense of small shareholders. Troung and Heany (2007) and Claessens et al. (2002) explain that large shareholders, compared with other shareholders, have distinguishing characteristics and an influential impact on firms' decision-allied underinvestment costs. Johnson et al. (2000) argue that large and controlling shareholders might use their advantage to enhance their personal interests in a way that expropriates profitable business opportunities from the firm. Claessens and Djankov (1999) add that a concentration of ownership maximizes the latent risk of expropriating small shareholders and the risk of descending-sloping firm values. 
Gugler and Yurtoglu (2003), who examine the German market, indicate that an increase in large shareholders results in weak small shareholders, and thus, these shareholders are reluctant to ask for cash dividends. Gutierrez and Tribo (2008), examining a Spanish firm, emphasize that if a large shareholder is - to a great extent - larger than the rest, it is likely that the number of small shareholders sharing private benefits will diminish. These explanations are in line with Renneboog and Trojanowski (2007), who examine five European countries; Truong and Heaney (2007), who examine 27 countries around the world; Mancinelli and Ozkan (2006), who examine companies in Italy; and Maury and Pajuste (2002), who examine dividend policies in Finland. These authors find that large shareholders may collude in generating private advantages that are not shared with minority shareholders as indicated by lower dividend payout levels.

Hanazaki et al. (2004) argue that banks, insurers, and non-financial corporations, predominantly the top-five largest shareholders, do not play a role in monitoring the managers of Japanese firms. This argument builds when they find that, as total loan and real estate loans rise, firm performance drops. They believe that this negative relationship occurs when the top-five largest shareholders collude or conspire with management. Hanazaki et al. (2004) suggest that the reasons for such a reaction are, first, that managers have strong business relationships with banks and insurance companies that possess shares, and second, there is weak corporate governance in Japan.

According to the above, this paper hypothesizes the following:

$\mathrm{H} 2$ : Large shareholders negatively affect dividend payout decisions.

\section{Ownership Structures of Listed Firms in the GCC States: An Outlook}

The ownership structures among shareholding companies listed on the stock exchanges of the GCC countries comprise governments and the private sector, which mainly represents individuals and institutional ownership.

Governments play a primary role in the listed firms of the GCC states. The government's role is even greater than that of other large shareholders for several reasons:

1). The government, as the sole owner of oil resources and revenue, is a large investor in both the public and private sectors.

2). The government is legally and practically bound to invest a fraction of its oil revenue under the General Reserve, Investment Reserve, or Future Generation Reserve, as in Kuwait. Kuwait and Qatar have allocated one-quarter of government oil revenues since as early as 1950. Bahrain has done so since the late 1930s (Al-Kuwari, 1978).

3). With its financial power and the need to diversify income resources, the government's role in economic development is to invest in economic projects in various sectors, such as financial, manufacturing, and services. Government investments take several forms:

- Projects wholly owned by the government (public enterprises).

- Participation with other governments and foreign investors (joint ventures).

- Participation with shareholding companies. The government plays a part in such companies beyond shareholder rights (other shareholders, or exceeding their shareholdings). The government presumes a principal role in controlling those companies in which it participates in the private sector. Here, the government serves as the backbone of the shareholding companies it initiates.

- Sale of companies totally or partly owned by the government to the private sector for privatization purposes.

Government ownership and development roles offer governments the capability and authority to control those companies in which they own shares, albeit such shares comprise less than $50 \%$ or even less than $25 \%$ of a company's total capital.

From the names dominating many boards of directors, it can be concluded that families control small and medium-sized firms and monopolize shares by keeping them in the hands of family members.

In light of the above regarding the leading, and relatively dominating, role of governments in the public shares of companies in the GCC states, ownership type is categorized primarily into two major groups: government control of shareholding companies and its agencies and private sector ownership, which is concentrated in a handful of large shareholders. Each ownership structure will be discussed below.

\subsection{Government Ownership}

The previous section shows that, in the GCC member states, government ownership is an important component of the control and management of the firms in which it holds shares. The government manipulates firm decisions and 
establishes policies, including dividend policies, although it may hold only a minor portion of shares. Typically, GCC states' governments own a significant amount of capital. For example, the government sector in Saudi Arabia owns around $70 \%$ of Saudi Basic Industries Corp. (SABIC), the largest company traded on the Saudi Stock Exchange. In Bahrain, the government sector owns more than $50 \%$ of shares in the Bahrain Telecommunications Company (Balteco) and the Bahrain Tourism Company.

Government ownership has a clearer form in Kuwait compared to other GCC states. Government ownership in Kuwait takes the appellation, "The Public Organisation for Investment" (POI), which is governed by the Ministry of Finance. In the early 1990s, the POI held the majority of the stock market's shares; this great ownership is a consequence of the Ministry of Finance's involvement in addressing the problems of the financial crises of 1978 and 1982 and in rescuing the banking system. At this time, shares are financed by domestic loans and investment firms. Therefore, the POI's ownership of public share companies is not driven by the aims of obtaining returns or maximizing capital value (Al-Shall, 2005).

However, by the mid-1990s, the POI, in line with its privatization policy, switched over to sell shares as ownership transfer routes. Such transfer procedures corresponded with the accessibility of great liquidity and led to a functional movement in Kuwait's stock market. This transfer program was terminated after 1997 as an outcome of the stock market's under-performance during the previous four years (Al-Shall, 2005).

The government does own additional public institutions, including the Social Insurance Corporation, a general institution that invests its money in domestic firms and plays a neutral role in the decision-making process of its board of directors (Al-Shall, 2005).

\subsection{Private Sector Ownership}

The private sector largely comprises members of royal or wealthy families whose names are repeated in numerous firms. This type of ownership typically takes place on boards of directors and plays a powerful role in decision making. However, only Oman stock discloses information about its large shareholders in the private sector.

Disclosure of ownership structures varies among the GCC states. Oman discloses information about government ownership, institutional ownership, and large shareholders exceeding $10 \%$ in the Muscat Stock Exchange's investment guide. Kuwait discloses information about government ownership and institutional ownership in the Kuwaiti national newspaper, while Saudi Arabia, Qatar, and Bahrain disclose information only about government ownership in the Gulf Investment Guide.

\section{Formal Model, Study Prediction and Variables Employed}

To test the impact of large shareholders on the dividend policy of firms listed on the KSE, two models apply. Model 1 examines the impact of large shareholders - those that own more than $5 \%$ of a firm's shares - regardless whether the large shareholders are government, institutions, or individuals. Model 2 examines different types of large shareholders, including institutional shareholders, government shareholders, and other large shareholders (e.g., families and individuals) and distinguishes among them. The distinction is made because different types of controlling owners may influence dividend policies differently.

Therefore, the two models are as follows:

Model 1:

$\mathrm{DIV}=\mathrm{f}(\mathrm{LSH}, \mathrm{FCF}, \mathrm{SIZE}, \mathrm{GROW}, \mathrm{LEV}, \mathrm{BETA}$, PROF $)$

Model 2:

$\mathrm{DIV}=\mathrm{f}(\mathrm{GOV}$, INST, OLSH, FCF, SIZE, GROW, LEV, BETA, PROF $)$

DIV, the dividend payout ratio, indicates the percentage of profits distributed by the company among shareholders out of net profits. Most previous studies that investigate the impact of dividend-agency theory employ dividend payout ratios as a determinant of dividends in lieu of dividend per share and dividend yield (See, for example, Rozeff, 1982; Lloyd et al., 1985; Jensen et al., 1992; Dempsey and Laber, 1992; Alli et al., 1993; Moh'd et al., 1995; Holder et al., 1998; Chen and Steiner, 1999; Saxena, 1999; Mollah et al., 2002; Manos, 2002; Travlos, 2002).

LSH represents the percentage of shares all large shareholders own, whether the large shareholders are governments, institutions, or other large shareholders. According to the literature review, two arguments are developed; the first implies a positive relationship between dividends and large shareholders (H1) as a significant instrument to monitor firm performance. Thus, large shareholders employ vetoing power for payout decisions, since dividend payouts reduce the cost of free cash flows and enhance monitoring by outsiders (e.g., Grinstein and Michaely, 2005; Redding, 
1997; Eckbo and Verma, 1994; Shleifer and Vishny Easterbrook, 1984). On the other hand, a contrasting argument suggests that, although large shareholders can monitor manager performances, they also may collude in generating private advantages that are not shared with minority shareholders, as indicated by lower dividend payout levels (e.g., Gutierrez and Tribo, 2008; Renneboo and Trojanowski, 2007; Mancinelli and Ozkan, 2006; Gugler and Yurtoglu, 2003).

INST refers to the percentage of shares institutions own. Shleifer and Vishny (1986), Allen and Michaely (2001), and Eckbo and Verma (1994) support a positive relationship between institutional ownership and dividend payout policy, while Horiuchi $(2002,2003,2004)$ supports a negative relationship.

GOV is the percentage of shares the government holds. Few studies examine the impact of government ownership. Gugler (2003), Glen et al. (1995), and La Porta et al. (2000) suggest a positive relationship between government ownership and dividend payout policy. Gugler (2003) suggests that governments might utilize dividend payout decisions to reduce the complex setting of agency problems. Glen et al. (1995) and La Porta et al. (2000) show that government ownership motivates firms to pay high dividends in order to reduce agency conflicts, especially in emerging countries in which the legal protection for minority shareholders is poor for outside shareholders. Thus, government, as a powerful investor, monitors firms' management performance by obligating them to distribute dividends. Such outcomes of government ownership safeguard outside shareholder rights from insider exploitation and reduce agency conflict, thereby preserving and improving firm reputation.

OLSH represents the percentage of shares held by other large shareholders (e.g., individual large shareholders). In this case, a negative consequence of the presence of large shareholders can be assumed, because large shareholders tend to act for their own benefit and provide private benefits for themselves.

Free cash flow (FCF) is a measure of how much cash a company has for ongoing activities and growth after paying expenses. Jensen (1986) defines FCF as cash flow in excess of the funds required for all projects with a positive net present value (NPV). He demonstrates that, as FCF increases, agency conflict arises between the interests of managers and outside shareholders, leading to a decrease in company performance. While shareholders want managers to maximize the value of their shares, managers may have different interests and derive benefits for themselves. Jensen's FCF hypothesis is supported by subsequent studies by Jensen et al. (1992) and Smith and Watts (1992). La Porta et al. (2000) find that, when a firm has FCF, its managers engage in wasteful practices, even when the protection of investor interests improves. Jensen (1986), Holder et al. (1998), and La Porta et al. (2000) suggest that firms with a greater FCF need to pay more dividends in order to reduce the agency costs of FCF. However, based on the findings of most previous studies, as the payment of dividends increases, agency costs of free cash decrease. FCF is calculated thus: net profit - changes in fixed assets - changes in net working capital)/total assets.

SIZE is measured as a natural logarithm of market capitalization. Jensen and Meckling (1976), Smith (1977), Lloyd et al. (1985), Eddy and Seifert (1988), Alli et al. (1993), Jensen et al. (1992), Redding (1997), Holder et al. (1998), and Fama and French (2001) indicate that large firms will choose to pay a higher dividend ratio than small firms in order to reduce agency costs. Large companies are associated with high agency costs, since widespread ownership has more bargaining power and the influence of widespread ownership increases agency costs.

GROW is measured as the growth rate of sales (e.g., Rozeff, 1982; Lloyd et al., 1985; Jensen et al., 1992; Alli et al., 1993; Moh'd et al., 1995; Holder et al., 1998; Chen and Steiner, 1999; Saxena, 1999; Manos, 2002; Travlos, 2002). Rozeff (1982), Lloyd et al. (1985), Dempsey and Laber (1992), Moh'd (1995), and Fama and French (2001) show that firm growth rate is a significant and negative explanatory variable of dividend payment. They argue that, since firm growth requires higher investment expenditures and external financing is costly, then firms with a high growth rate will choose to pay lower dividends. On the other hand, firms will pay dividends only when internally generated funds are not completely used up by investment. Myers (1984) states that investment opportunities reduce the agency problem because they reduce the free cash available to managers; therefore, investment opportunities can act as substitutes for dividend payouts for the purpose of reducing the agency problem.

LEV refers to the leverage ratio measured as the debt-to-equity ratio. Firm leverage is an important and significant factor that is used to explain dividend policy (e.g., Rozeff, 1982; Chang and Rahee, 1990; Jensen et al., 1992; Moh'd et al., 1995; Chen and Steiner, 1999). Jensen et al. (1992), Agrawal and Jayaraman (1994), Crutchley and Hansen (1989), Faccio and Lang (2002), and Gugler and Yurtoglu (2003) propose that financial leverage negatively affects dividend policy. Their studies infer that highly leveraged firms look forward to maintaining their internal cash flows to fulfill their duties instead of distributing available cash to shareholders and also to protect their creditors. This explanation is in line with Jensen and Meckling (1976) and Jensen (1986), who explain that the negative association 
between firm leverage and agency cost is because leverage might play a significant part in monitoring managers, thereby reducing agency costs that occur from the conflicts that arise between managers and shareholders.

BETA, which is a mathematical measure of the sensitivity of the rates of return on a given stock compared with the rates of return in the market as a whole, is used as a proxy for business risk (e.g., Rozeff, 1982; Lloyd et al., 1985; Jensen et al., 1992; Alli et al., 1993; Moh'd et al., 1995; Holder et al., 1998; Chen and Steiner, 1999; Saxsena, 1999; Manos, 2002). Business risk increases the uncertainty of the direct relationship between current and expected future profit. Hence, firms avoid the commitment to pay high dividends as their uncertainty about earnings increases (for example, Rozeff, 1982; Lloyd et al., 1985; Alli et al., 1993; Moh'd et al., 1995; Casey and Dickens, 2000), where beta is used as a measurement of a stock's volatility in relation to the market.

PROF is the ratio of net profit to the amount of money shareholders have invested in the company. Return on equity is used in several studies as a proxy for firm profitability (e.g., Aivazian et al., 2003; Ap Gwilym et al., 2004.) The financial literature documents that a firm's profitability is a significant and positive explanatory variable of dividend policy (Jensen et al., 1992; Han et al., 1999; Fama and French, 2001). However, Glen et al. (1995) report that there is a significant difference between dividend policies in developed and developing countries, that emerging market corporations do not follow a stable dividend policy, and that dividend payment for a given year is based on firm profitability for the same year. Adaoğlu and Impson (2000) state that the main determinant for the amount of cash dividend in the Istanbul Stock Exchange is earnings for the same year. Any variability in the earnings of corporations is directly reflected in the cash dividend level there. Pandey (2001) reports a similar result for Malaysian firms. Al-Malkawi (2008) identifies the profitability ratio as the key determinant of corporate dividend policy in Jordan. La Porta et al. (2000) indicate that, in countries where legal protection is limited, shareholders take whatever cash dividend they can get from firm profits, where the dividend is unstable.

Table 1 summarizes the basic variables employed and the predicted signs for the corresponding regression coefficients.

$<$ Insert Table 1 Here $>$

\section{Data Collection and Preliminary Firm Descriptions}

This study examines a sample of 37 non-financial firms listed on the KSE at the end of 2003 (Gulf Investment Guide, 2004).

The dividend payout ratio and factors affecting dividends for the 37 non-financial firms for the period 1999 to 2003 are collected. The primary sources of these data are the 2004 Gulf Investment Guide (GIG) and the directory of the KSE. These are useful sources for obtaining all of the variable data, except for the business risk variable. Data on the business risk of all firms listed on the KSE is collected from unpublished data issued by Zughaibi and Kabbani Financial Consulting.

The dependent variable of the models to be estimated is whether a firm pays a dividend in a specific year or not. If a firm pays a dividend in a specific year, then the dependent variable is taken as 1 ; otherwise it is taken as 0 . Of all of the observations (i.e., 185), we find that $48.4 \%$ of firms do not pay dividends for a year, while $51.6 \%$ firms do pay dividends. Table 2 (below) presents descriptive statistics for the variables included in the models to examine the dividend policy of non-financial companies listed on the stock exchanges of the GCC states for the period of 1999 to 2003.

$<$ Insert Table 2 Here $>$

Based on the 37 non-financial firms for which the data are available, it is established that the average cash dividend ratio paid by the firms for the period $1999-2003$ is $55 \%$. However, it is important to note here that the firms in which the government owns a percentage of the shares pay almost $90 \%$ of their net profit, on average, while firms owned entirely by the private sector pay around $43 \%$. It is also found that most of the firms in which the government owns a proportion of shares normally pay a dividend. This is because $16 \%$ of the observations of firms partly owned by the government have zero dividends, relative to $44 \%$ of the observations of firms completely owned by the private sector, which have zero dividends. Therefore, the random-effects probit model is an appropriate method to test the dividend decisions of firms listed on the KSE.

\section{Methodology}

Our dependent variable is a binary variable indicated by 1 and 0 , in which 1 suggests that a firm pays dividends to its shareholders, and 0 suggests that a firm does not. The purpose is to identify the firm's characteristics that lead to its decision to pay or not pay dividends. A review of the literature suggests that a suitable model for such a dependent 
variable is either a probit or logit model (Long, 1997). Since both logit and probit formulations provide similar results, a probit model is considered in this study. Long (1997) suggests that the coefficients from the logit model are 1.6 to 1.8 times larger than those for the probit model.

The probit model is usually formulated in a latent (i.e., unobserved) variables framework. The general specification (Note 3) is (Long, 1997):

$$
y_{i}^{*}=\boldsymbol{X}_{i} \boldsymbol{\beta}^{\prime}+\varepsilon_{i}
$$

where $y_{i}^{*}$ is a continuous, latent (unobserved) variable measuring the firm's willingness to pay (or not pay) dividends for $i^{\text {th }}$ firm; $\boldsymbol{X}_{\boldsymbol{i}}$ is a $(\mathrm{k} \times 1)$ vector of observed explanatory variables; $\boldsymbol{\beta}$ is a $(\mathrm{k} \times 1)$ vector of unknown parameters to be estimated; and $\varepsilon_{i}$ is the random error term that has a normal distribution with a mean of 0 and a variance of 1 .

The unobserved variable $y_{i}^{*}$ is linked with the observed binary variable $y_{i}$ by the following measurement equation:

$$
y_{i}= \begin{cases}1 & \text { if } y_{i}^{*}>\phi \\ 0 & \text { if } y_{i}^{*} \leq \phi\end{cases}
$$

in which $\phi$ is known as the threshold, and it is assumed that $\phi=0$ for the binary response variable.

The probability that the outcome is 1 can be expressed as follows:

$$
\operatorname{Pr}(y=1 \mid \boldsymbol{X})=\Phi\left(\boldsymbol{X} \boldsymbol{\beta}^{\prime}\right)
$$

in which $\Phi$ is the cumulative distribution function for the standard normal distribution. The parameters $\boldsymbol{\beta}$ are typically estimated by the method of maximum likelihood.

Since the dataset used in this study is a panel dataset, a fixed-effects or random-effects probit model is more appropriate, and as such, the model can take into account the unobserved heterogeneity normally found in a panel dataset. The estimation of a fixed-effects probit model is complex (STATA, 2006); therefore, a random-effects probit model is used. The model can be expressed as:

$$
\operatorname{Pr}\left(y_{i t}=1 \mid \boldsymbol{X}_{i t}\right)=\Phi\left(\boldsymbol{X}_{i t} \boldsymbol{\beta}^{\prime}+v_{i}\right)
$$

in which $i=1, \ldots \ldots \ldots, N$ are cross-sectional units and $t=1, \ldots \ldots \ldots, T$ are time-series units, and $v_{i}$ is the random-effects among the cross-section which are assumed to be independently and identically distributed with zero means and a constant variance. If $\sigma_{v}^{2}$ represents the panel-level variance, then the total variance can be expressed as $\rho($ rho $)$ :

$$
\rho=\frac{\sigma_{v}^{2}}{1+\sigma_{v}^{2}}
$$

If $\rho$ is found to be zero, then the panel-level variance becomes unimportant, suggesting that the panel estimator is not different from the pooled estimator.

A random-effects probit model can be estimated using a maximum likelihood method in which the log likelihood is calculated using either adaptive or nonadaptive Gauss-Hermite quadrature (Liu and Pierce, 1994).

\section{Results}

The primary objective of this paper is to investigate how ownership structure and agency theory can explain the decision to pay or not to pay dividends, based on a panel dataset from non-financial firms listed on the KSE. A random-effects probit model is used to achieve the study objective. Prior to the model's results, a pair-wise correlation matrix and a variance inflation function (VIF) are examined to ensure that there is no multicollinearity between the explanatory variables. The results of the pair-wise correlation matrix explanatory variables are shown in Table 3. It should be noted that the correlation coefficients between most pairs of explanatory variables are low, suggesting that there is no multicollinearity problem among these explanatory variables. However, there is a strong correlation between large shareholders; this indicates that a significant number of large shareholders are institutions. This is because government and institutions form part of the large shareholder group (68\%). The impact of large 
shareholders on dividend decisions is examined in Model 1, while institutional ownership is examined in two different models.

$<$ Insert Table 3 Here $>$

The results using the variance inflation factor (VIF) are presented in Table 4. As can be seen, the mean VIF is 1.08, which is very low relative to the threshold value of 10 . The VIF for each variable is also very low. This indicates that the explanatory variables included in the model are not substantially correlated with each other.

$<$ Insert Table 4 Here $>$

Two random-effects probit models are then estimated and the results are shown in Table 5.

$<$ Insert Table 5 Here $>$

\subsection{Discussions on Model with Large Shareholders (Model 1)}

The hypothesis discussed earlier indicates that dividend payout is positively/negatively associated with the percentage of shares owned by large shareholders. Surprisingly, the results from Model 1 suggest that large shareholders do not affect dividend payout decisions. As such, this result does not support previous studies that find a negative association between dividend payout decision and large shareholders. For example, the results fail to support the argument of Claessens et al. (2002), who indicate that large shareholders adopt large dividend payouts as a mechanism of maintaining firm value and enhancing the firm's reputation for not expropriating the wealth of its minority shareholders. Furthermore, the results do not support the hypothesis of Grinstein and Michaely (2005), Shleifer and Vishny (1986), and Grossman and Hart (1980), who find that large shareholders play a significant part in monitoring managers and inside shareholder performances and large shareholders have an inducement and make an effort to bear the cost of monitoring, since the consequences and returns from monitoring surpass the cost.

The results also do not support the hypothesis that large shareholders negatively affect dividend payout decisions in that they may collude in generating private advantages that are not shared with minority shareholders, as indicated by lower dividend payout levels (e.g., Pergola and Verreault, 2009; Mancinelli and Ozkan, 2006; Gugler and Yurtoglu, 2003; Shleifer and Vishny, 1997; Demsetz and Lehn, 1985).

The insignificant relationship between dividend payouts and large shareholders may be related to the possibility that large shareholders, who are often controlling shareholders, do not bother distributing shareholders. Another reason may be related to the possibility that different large shareholders (e.g., government, institutions, and individuals) have different impacts on dividend payment decisions. In other words, different large shareholders do not make similar decisions in paying dividends. This might be diluted by the presence of large shareholders' influences as a whole, causing an insignificant relationship overall between large shareholders and dividend payout policies. However, Model 2 (as discussed below) disaggregates the large shareholders and re-examines their influences on dividend policies.

The results from Model 1 show that only two agency variables - leverage ratio and firm profitability - are significant, while free cash flows, firm size, and business risk appear to be insignificant variables.

Leverage ratio emerges as a statistically significant variable affecting firm decisions to pay dividends. This result is consistent with the prediction that there is low probability that a highly leveraged firm will decide to pay dividends. On the other hand, low-leveraged firms have a higher probability of deciding to pay dividends (e.g., 1979; Rozeff, 1982; Chang and Rahee, 1990; Jensen et al., 1992; Moh'd et al., 1995; Chen and Steiner, 1999). These results support Jensen and Meckling (1976) and Jensen (1986), who explain that high leverage is an alternative to dividend payments in reducing agency costs. That is, leverage might play a significant part in monitoring managers, thereby reducing the agency costs that result from conflicts between managers and shareholders.

This result explains that financial leverage negatively affects dividend policies because highly leveraged firms keep their internal cash flow to meet obligations and protect creditors. Furthermore, the high leverage ratio is a sequence to dividend, where high leverage might play a significant part in enabling creditors to monitor managers, thereby reducing the agency costs that result from a conflict between managers and shareholders (Faccio and Lang 2002; Gugler and Yurtoglu, 2003; Jensen and Meckling, 1976; Jensen, 1986).

The second significant variable is firm profitability. The results show that there is a higher probability that firms will decide to pay dividends when they realize high profit for the same year. This result supports the suggestion that there is a direct relationship between the probability of dividend decision and firm profitability. 
These results are consistent with those of Adaoğlu and Impson (2000), who state that earnings for the same year are the primary determinant of the amount of cash paid as dividends on the Istanbul Stock Exchange and any change in the earnings of corporations directly affects the payment of these dividends. Furthermore, Pandey (2001), Al-Malkawi (2008), and Al-Kuwari (2009) find that the profitability ratio is an important determinant of corporate dividend policy in emerging markets. La Porta et al. (2000) find that, in countries where legal protection is limited, shareholders will take whatever cash dividend they can get from firm profits when the allocation of dividends is unpredictable.

\subsection{Discussions on Model with Different Types of Large Shareholders (Model 2)}

Model 1 shows that the large shareholders variable does not affect dividend decisions. This may be due to the fact that types of shareholders may play a role in deciding whether or not to pay a dividend. Therefore, Model 2 re-examines the impact of large shareholders by classifying them into three groups: government, institutions, and other large shareholders. The results are reported in Table 5, which shows that the government shareholder appears to be the only statistically significant large shareholder that may affect dividends. It should be noted that the government owned, on average, only $9 \%$ of firm shares.

The significance of government as a large shareholder implies that, when legal protection for outside shareholders is poor, as in developing markets, government plays a significant role in monitoring managers and inside shareholders by obligating the firm to pay dividends. Such outcomes of government ownership safeguard outside shareholder rights from insider exploitation, thereby maintaining firm reputation and reducing agency problems (Glen et al., 1995; La Porta et al., 2000, Gugler (2003). This explanation is in line with Claessens et al. (2002), who indicate that the largest shareholders may prefer to pay dividends with the intention of diminishing the extraordinary costs of monitoring, enhancing monitoring efficiency, boosting firm value and maintaining firm reputation for not expropriating small shareholders' wealth.

Furthermore, the results provide two important characteristics related to the economies of GCC stats. First it shows that the economic and social activities of Kuwait, as in other GCC states, depend immensely on a government budget based principally on revenue from exporting crude oil. However, according to oil price oscillations, in addition to the high financial costs of Gulf Wars, deficits have cropped up and turned out to be lasting in the budgets of GCC states. Therefore, the GCC governments espouse a number of strategies aimed at expanding and verifying their economic resources with the purpose of moderating their extreme dependency on oil revenue and public sector expenditures. The intention of these strategies is to encourage investors to invest in the private sector; paying dividends is a substantial instrument governments employ to enhance firm reputations for not exploiting minority shareholders, thereby attracting the public to invest in the private sector. Second, these results highlighted that, in the GCC states, governments are dominating the private sector. Throughout the GCC states, there is widespread government intervention in economic activity, which is related to government control over the most important national asset: oil. Thus, oil revenue enables the government to make economic decisions without regard for the private sector. Therefore, the relationship between the government and public and private sectors, in this situation, is subordinated because the private sector depends on the plans for public expenditure and government spending, which represent a hindrance to the role of the private sector.

While government ownership appears to be a significant variable, surprisingly, institutions that own an average of $29 \%$ of firms' shares appear to be a statistically insignificant variable. The lack of significance found here conflicts with Zeckhauser and Pound (1990), who find that the presence of institutional investors enables firms to distribute dividends, since institutions have the skills to monitor and evaluate manager performances. It also conflicts with the studies of Shleifer and Vishny (1986) and Moh'd et al. (1995), who indicate that firms that have institutional ownership pay higher dividends with the aim of attracting large shareholders. The results also do not support Hanazaki et al. (2004) in that institutional ownership might collude or conspire with firm managers.

These results do not support Eckbo and Verma (1994), who imply that institutional shareholders may favor cash dividends to facilitate reduced agency costs of free cash flow. The results also fail to assist the argument of Zeckhauser and Pound (1990), who propose that institutions might utilize their vetoing power to induce firms to make dividend decisions.

Other large shareholders also appear to be insignificant large shareholders, which contrasts with numerous predictions (e.g., Pergola and Verreault, 2009; Mancinelli and Ozkan, 2006; Gugler and Yurtoglu, 2003; Claessens et al., 2002; Shleifer and Vishny, 1997; Shleifer and Vishny, 1986; Demsetz and Lehn, 1985; Grossman and Hart, 1980). 
As shown in Models 1 and 2, leverage ratio and firm profitability appear as statistically significant variables in explaining dividend decisions, while free cash flow, firm size, and business risk appear as insignificant variables.

In summary, this study indicates that the dividend decisions of firms listed on the KSE are based on government ownership, firm leverage, and firm profitability. The results also suggest that government is the only type of large shareholder that can affect dividend decisions and thereby increase the monitoring. On the other hand, other types of large shareholders - such as institutions - do not have any influence on dividend decisions.

\section{Conclusion}

This paper investigates the impact of large shareholders in explaining the dividend policy decisions of companies listed on the KSE as an example of emerging markets. The models are developed using random-effect probit specifications based on a panel dataset consisting of observations from 37 companies over five years.

The results reveal that government is the only large shareholder that affects positively the dividend decisions for firms listed on KSE. Furthermore, the results show that government ownership and firm profitability increase the probability of paying dividends, while leverage ratio decreases the probability. Overall, the findings indicate that companies listed on the KSE pay dividends in order to monitor corporate management, reduce agency conflict, and maintain the firm's reputation of not exploiting minority shareholders.

\section{References}

Adaoğlu, C., \& Impson, M. (2000). Stability in the Dividend Policy of the Istanbul Stock Exchange (ISE) Corporations: Evidence from an emerging market. Emerging Markets Review, 1, 252-270.

Agrawal, A., \& Jayaraman, N. (1994). The Dividend Policies of All-equity Firms: A direct test of the free cash flow theory. Managerial and Decision Economics, 15, 139-148.

Aivazian, V., Booth, L., \& Cleary, S. (2003). Do Firms in Emerging Markets Follow Different Dividend Policies from U.S. Firms? Journal of Financial Research, 26, 371-387.

Allen, F., \& Michaely, R. (2001). Payout policy. In G. Constantinides, M. Harris, and R. Stulz (Eds.), Handbook of Economics. North-Holland.

Al-Kuwari, A. (1978). Oil revenues in the Gulf Emirates: Patterns of allocation and impact on economic development. Bowker, Epping, UK.

Al-Kuwari, D. (2012). Dividend policy and agency theory in emerging stock exchanges: The case of GCC countries. Lambert Academic Publishing, Saarbrucken, Germany.

Al-Kuwari, D. (2009). Determinants of the dividend policy in emerging stock exchanges: The case of GCC countries. Global Economy \& Finance Journal, 2, 38-63.

Alli, K., Khan, A., \& Ramirez, G. (1993). Determinants of Corporate Dividend Policy: A factor analysis. Financial Review, 28, 523-547.

Al-Malkawi, H. (2008). Factors Influencing Corporate Dividend Decision: Evidence from Jordanian panel data. Journal of Economics and Administrative Sciences, 2, 44-71.

Al-Shall Economic Consultants. (2005). Ownership structure of firms listed on the Kuwait Stock Exchange. Unpublished report.

Al-Ibrahim, Y. (2004). A Radical Reform in the Cooperation Council of Arab Gulf States. Dar Kurtas Publishing, Kuwait.

Ap Gwilym, O., Seaton, J., \& Thomas, S. (2004). Dividends Aren't Disappearing: Evidence from the UK. Working Paper, University of Southampton.

Berle, A., \& Means, Jr., G. (1932). The Modern Corporation and Private Property (Revised Edition 1967). New York: Harcourt Brace and World Inc.

Casey, K., \& Dickens, R. (2000). The effects of tax and regulatory changes on commercial bank dividend policy. Quarterly Review of Economics and Finance, 40, 279-293.

Chang, R., \& Rahee, S. (1990). The impact of personal taxes on corporate dividend policy and capital structure decision. Financial Management, 19, 21-31.

Chen, C., \& Steiner, T. (1999). Managerial Ownership and Agency Conflicts: A nonlinear simultaneous equation analysis of managerial ownership, risk taking, debt policy, and dividend policy. Financial Review, 34, 119-136. 
Chen, X., \& Sinha, A. (2011). Large Shareholders and Dividends: Game theoretic analysis of shareholder power. Department of Finance, College of Business Administration. [Online] Available: http://69.175.2.130/ finman/Orlando/Papers/LargeShareholdersandDividendsGameTheoreticAnalysisofSh.pdf (May $25,2011)$

Claessens, S., \& Djankov, S. (1999, September). Ownership Concentration and Corporate Performance in the Czech Republic. Journal of Comparative Economics, 27, 498-513.

Claessens, S., Djankov, S., \& Lang, L. (2000). The Separation of Ownership and Control in East Asian Corporations. Journal of Financial Economics, 58, 81-112.

Claessens, S., Djankov, S., Fan, J. P. H., \& Lang, L. H. P. (2002). Disentangling the Incentive and Entrenchment Effects of Large Shareholdings. Journal of Finance, 57, 2741-2771.

Crutchley, C., \& Hansen, R. (1989). A test of the agency theory of managerial ownership, corporate leverage and corporate dividends. Financial Management, 18, 36-46.

Dempsey, S., \& Laber, G. (1992). Effects of Agency and Transaction Cost on Dividend Payout Ratios: Further evidence of the agency-transaction cost hypothesis. Journal of Financial Research, 15, 317-321.

Demsetz, H., \& Lehn, K. (1985). The Structure of Corporate Ownership: Causes and consequences. Journal of Political Economy, 93, 1155-1177.

Easterbrook, F. (1984). Two Agency Cost Explanations of Dividends. American Economic Review, 74, 650-659.

Eckbo, B., \& Verma, S. (1994). Managerial Share Ownership, Voting Power and Cash Dividend Policy. Journal of Corporate Finance, 1, 33-62.

Eddy, A., \& Seifert, B. (1988). Firm Size and Dividend Announcements. Journal of Financial Research, 11, 295-302.

Faccio, M., \& Lang, L. (2002). The Ultimate Ownership of Western European Corporations. Journal of Financial Economics, 65, 365-395.

Fama, E., \& French, K. (2001). Disappearing Dividends: Changing firm characteristics or lower propensity to pay? Journal of Financial Economics, 60, 3-43.

Glen, D., Karmokolias, Y., Miller. R., \& Shah, S. (1995). Dividend Policy and Behavior in Emerging Markets: To pay or not to pay. IFC Discussion Paper No: 26. [Online] Available: http://www.ifc.org (Nov. 7, 2010)

Grinstein, Y., \& Michaely, R. (2005). Institutional Holdings and Payout Policy. Journal of Finance, 60, 1389-1426.

Grossman, S., \& Hart, O. (1980). David A. Currie and William Peters. ed. Take-Over Bids: The Managerial Theory of the Firm and the Free Rider Problem. Croom Helm London, pp. 461-468.

Gugler, K. (2003). Corporate Governance, Dividend Payout Policy, and the Interrelation between Dividends, R\&D, and Capital Investment. Journal of Banking and Finance, 27, 1297-1321.

Gugler, K., \& Yurtoglu, B. (2003). Corporate Governance and Dividend Payout Policy in Germany. European Economic Review, 47, 731-758.

Gul, F. (1999). Government Share Ownership, Investment Opportunity Set and Corporate Policy Choices in China. Pacific-Basin Finance, Journal, 7, 157-172.

Gulf Investment Guide. (2004). Zughaibi \& Kabbani Financial Consultants, Kingdom of Saudi Arabia.

Gutierrez, M., \& Tribo, J. A. (2008). Ownership Structure and Minority Expropriation in Non-listed Firms: The case for multiple large shareholders. Working paper series.

Han, K., Lee, S., \& Suk, D. (1999). Institutional Shareholders and Dividend. Journal of Financial and Strategic Decisions, 12, 53-62.

Hanazaki, M., Souma, T., \& Wiwattanakantang, Y. (2004). Silent Large Shareholders and Entrenched Bank Management: Evidence from the banking crisis in Japan. Hitotsubashi University, Center for Economic Institutions. Working Paper No. 2004/1.

Holder, M., Langrehr, F., \& Hexter, J. (1998). Dividend Policy Determinants: An investigation of the influences of stakeholder theory. Financial Management, 2, 73-82. 
Holderness, Clifford G. (2003). A Survey of Blockholders and Corporate Control. Economic Policy Review, 9, 51-63.

International Monetary Fund. (2010). Country information. [Online] Available: www.imf.org (Dec. 31, 2010)

Jensen, G., Solberg, D., \& Zorn, T. (1992). Simultaneous Determination of Insider Ownership, Debt, and Dividend Policies. Journal of Financial and Quantitative Analysis, 27, 247-261.

Jensen, M. (1986). Agency Costs of Free Cash Flow, Corporate Finance, and Takeovers. American Economic Review, 76, 323-329.

Jensen, M., \& Meckling, W. (1976). Theory of the Firm: Managerial behavior, agency cost and capital structure. Journal of Financial Economics, 3, 305-360.

Khan, T. (2006). Company Dividends and Ownership Structure: Evidence from UK panel data. Economic Journal, 116, 172-189.

La Porta, R., Lopez-De-Silanes, F., Shleifer, A., \& Vishny, R. (2000). Agency Problems and Dividend Policy around the World. Journal of Finance, 55, 1-33.

La Porta, R., Lopez-De-Silanes, F., Shleifer, A., \& Vishny, R. (1999). Corporate Ownership around the World. Journal of Finance, 54, 471-517.

Liu, Q., \& Pierce, D. (1994). A Note on Gauss-Hermite Quadrature. Biometrika, 81, 624-629.

Lloyd, W., Jahera, J., \& Page, D. (1985). Agency cost and payout ratios. Quarterly Journal of Economics, 24, 19-29.

Long, J. (1997). The Market Valuation of Cash Dividends: A case to consider. Journal of Financial Economics, 6, 235-264.

Mancinelli, L., \& Ozkan, A. (2006). Ownership Structure and Dividend Policy: Evidence from Italian firms. European Journal of Finance, 12, 265-282.

Manos, R. (2002). Dividend Policy and Agency Theory: Evidence on Indian firms. Working Paper. Institute for Development Policy and Management, University of Manchester.

Maury, B., \& Pajuste, A. (2002). Controlling Shareholders, Agency Problems and Dividend Policy in Finland. Finnish Journal of Business Economics, 51, 15-45.

McConnell, J., \& Servaes, H. (1990). Additional Evidence on Equity Ownership and Corporate Value. Journal of Financial Economics, 27, 595-612.

Miller, M., \& Modigliani, F. (1961). Dividend Policy, Growth, and the Valuation of Shares. Journal of Business, 34, pp. 411-433.

Moh'd, A., Perry, L., \& Rimbey, J. (1995). An Investigation of the Dynamic Relationship between Agency Theory and Dividend Policy. The Financial Review, 30, 367-385.

Morck, R., Shleifer, A., \& Vishny, R. (1988). Management Ownership and Market Valuation: An empirical analysis. Journal of Financial Economics., 20, 293-315.

Myers, S. (1984). The Capital Structure Puzzle. Journal of Finance, 39, 575-592.

Pandey, I. (2001). Corporate Dividend Policy and Behaviour: The Malaysian experience. Working Paper No. 2001-11-01. Indian Institute of Management Ahmedabad.

Pergola, T., \& Verreault, D. (2009). Motivations and Potential Monitoring Effects of Large Shareholders. Corporate Governance - International Journal of Business in Society, 9(5), 551-563.

Redding, L. (1997). Firm Size and Dividend Payouts. Journal of Financial Intermediation, 6, 224-248.

Renneboog, L., \& Trojanowski, G. (2007). Control Structures and Payout Policy. Managerial Finance, 33(1), 43.

Rozeff, M. (1982). Growth, Beta and Agency Cost as Determinants of Dividend Payout Ratios. Journal of Financial Research, 5, 249-259.

Saxena, A. (1999). Determinants of Dividend Policy: Regulated versus unregulated firms. [Online] Available: http://www.westga.edu/ bquest/1999/payout.html (Jan. 1, 2005)

Shleifer, A., \& Vishny, R. (1986). Large Shareholders and Corporate Control. Journal of Political Economy, 94, 461-488. 
Shleifer, A., \& Vishny, R. (1997). A Survey of Corporate Governance. Journal of Finance, 52, 737-783.

Short, H., Zhang, H., \& Keasey, K. (2002). The Link between Dividend Policy and Institutional Ownership. Journal of Corporate Finance, 8, 105-122.

Smith, C. (1977). Alternative Methods for Raising Capital: Rights versus underwritten offerings. Journal of Financial Economics, 50, 273-307.

Smith, C., \& Watts, R. (1992). The Investment Opportunity Set and Corporate Financing, Dividend and Compensation Policies. Journal of Financial Economics, 32, 263-292.

Stata Press. (2006). STATA Longitudinal/Panel Data Reference Manual. Release 9. College Station. STATA Press, Texas.

Travlos, N., Murinde, V., \& Naser, K. (2002). Dividend Policy of Companies Listed on Young Stock Exchanges: Evidence from the Muscat Stock Exchange. Working Paper.

Truong, T., \& Heaney, R. (2007). Largest shareholder and dividend policy around the world. The Quarterly Review of Economics and Finance, 47, 667-687.

Zeckhauser, R., \& Pound, J. (1990). Are Large Shareholders Effective Monitors? An investigation of share ownership and corporate performance. In R. Hubbard (Ed.), Asymmetric Information, Corporate Finance and Investment. Chicago University Press: Chicago.

\section{Notes}

Note 1. The Gulf Cooperation Council (GCC) states comprise a group of six oil-exporting Arab countries (Bahrain, Kuwait, Qatar, Saudi Arabia, Oman and the United Arab Emirates) founded in May 1981.

Note 2. GCC countries are unique among other developing countries because of their oil revenue. Therefore, they achieve significant levels of income, in some instances surpassing the per capita incomes of developed countries.

Note 3. See Long (1997) for a detailed description of the model.

Table 1. Summary of variables and research predictions

\begin{tabular}{|l|l|l|}
\hline Variable s & \multicolumn{1}{|c|}{ Description } & Predection \\
\hline DIV & Dividend payout ratio proxied by cash dividend to net profit & $(+)$ or $(-)$ \\
\hline LSH & Percentage of shares owned by large shareholders & $(+)$ \\
\hline GOV & Percentage of shares owned by government & $(+)$ or(-) \\
\hline INST & Percentage of shares owned by institutions & $(+)$ or $(-)$ \\
\hline LSHO & Percentage of shares owned by other large shareholders & $(+)$ \\
\hline FCF & $\begin{array}{l}\text { Free cash flow proxied by (net profit ? changes in fixed assets }- \text { changes in } \\
\text { net working capital)/total assets })\end{array}$ & $(+)$ \\
\hline SIZE & Log of market capitalization & $(+)$ or $(-)$ \\
\hline GROW & Firm growth rate of sales & $(-)$ \\
\hline LEV & Leverage ratio proxied by(firm leverage /shareholder抯 equity) & $(-)$ \\
\hline BETA & Business risk proxied by beta & $(+)$ \\
\hline PROF & Firm profitability proxied by return on equity & \\
\hline
\end{tabular}


Table 2. Descriptive statistics of the variables used in the study for non-financial companies listed on the Kuwait Stock Exchange for the period 1999-2003

\begin{tabular}{|l|l|l|l|l|l|}
\hline \multirow{2}{*}{ Variables } & \multirow{2}{*}{ Std. } & & & \\
\cline { 4 - 6 } & & & Q1 & Q2 & Q3 \\
\hline Dividend ratio (DIV) (yes=1 otherwise=0) & 55.594 & 74.469 & 0.000 & 48.300 & 80.600 \\
\hline Large shareholders (LSH) & 42.537 & 19.778 & 26.780 & 43.660 & 55.130 \\
\hline Government ownership (GOV) & 7.808 & 16.028 & 0.000 & 0.000 & 9.700 \\
\hline Institutional ownership (INST) & 29.082 & 21.025 & 9.460 & 26.000 & 47.330 \\
\hline Individual shareholders (LSIND) & 5.646 & 11.468 & 0.000 & 0.000 & 9.570 \\
\hline Free cash flow (FCF) & -0.002 & 0.297 & -0.120 & 0.020 & 0.120 \\
\hline Market capitalization (MC) 000 US & 281244 & 705311 & 44354 & 102231 & 229020 \\
\hline Growth rate (GROW) & 0.489 & 3.753 & 0.000 & 0.070 & 0.260 \\
\hline Firm leverage (LEV) & 67.382 & 77.489 & 13.200 & 45.800 & 89.600 \\
\hline Business risk (BETA) & 0.661 & 0.469 & 0.280 & 0.690 & 1.000 \\
\hline Firm profitability (PROF) & 12.095 & 19.061 & 4.000 & 10.500 & 18.000 \\
\hline
\end{tabular}

Table 3. Correlation coefficients among the explanatory variables

\begin{tabular}{|l|c|c|c|c|c|c|c|c|c|c|}
\hline \multicolumn{1}{|c|}{ Variables } & LSH & GOV & INS T & LSIND & FCF & MC & GROW & LEV & BETA & PROF \\
\hline Large shareholders (LSH) & 1.0000 & & & & & & & & & \\
\hline Government ownership (GOV) & 0.3853 & 1.0000 & & & & & & & & \\
\hline Ins titutional ownership (INST) & 0.6154 & -0.3004 & 1.0000 & & & & & & & \\
\hline Other large shareholders (LSHO) & 0.0578 & -0.1824 & -0.3521 & 1.0000 & & & & & & \\
\hline Free cash flow (FCF) & -0.0634 & -0.0147 & -0.0228 & -0.0471 & 1.0000 & & & & & \\
\hline Market capitalization (MC) & -0.1723 & 0.1868 & -0.1728 & -0.2415 & 0.0557 & 1.0000 & & & & \\
\hline Growth rate (GROW) & -0.0569 & 0.0550 & -0.0680 & -0.0504 & 0.0350 & -0.0007 & 1.0000 & & & \\
\hline Firm leverage (LEV) & -0.3685 & -0.2590 & -0.2290 & 0.1464 & 0.0021 & -0.1600 & -0.0033 & 1.0000 & & \\
\hline Bus ines s risk (BETA) & -0.1317 & -0.0322 & -0.1064 & 0.0131 & 0.0934 & 0.1856 & -0.0502 & 0.2871 & 1.0000 & \\
\hline Firm profitability (PROF) & -0.1499 & -0.0191 & -0.1741 & 0.0873 & 0.1655 & 0.3056 & 0.0105 & -0.0385 & 0.0943 & 1.0000 \\
\hline
\end{tabular}

Table 4. The variance inflation factor

\begin{tabular}{|l|c|c|}
\hline \multicolumn{1}{|c|}{ Variable } & VIF & $\mathbf{1} /$ VIF \\
\hline Institutional shareholders (INST) & 1.69 & 0.5919 \\
\hline Other large shareholders (OLSH) & 1.45 & 0.6903 \\
\hline Government ownership (GOV) & 1.42 & 0.7059 \\
\hline Firm leverage (LEV) & 1.39 & 0.7172 \\
\hline M arket capitalization (M C) US\$000 & 1.39 & 0.7194 \\
\hline Firm pro fitability (PROF) & 1.19 & 0.8428 \\
\hline Bus iness risk (BETA) & 1.17 & 0.8513 \\
\hline Free cash flow (FCF) & 1.04 & 0.9595 \\
\hline Growth rate (GROW) & 1.02 & 0.9831 \\
\hline
\end{tabular}


Table 5. Estimation results from a random-effects probit model

\begin{tabular}{|c|c|c|c|c|}
\hline \multirow[b]{2}{*}{ Explanatory Variables } & \multicolumn{2}{|c|}{ Model 1} & \multicolumn{2}{|c|}{ Model 2} \\
\hline & Coeff & t-s tat & Coeff & t-s tat \\
\hline Large shareholders(LSH) & 0.00281 & 0.33 & & \\
\hline Government ownership (GOV) & & & 0.0220 & 1.68 \\
\hline Ins titutional owners hip (INST) & & & -0.0059 & -0.67 \\
\hline Other large shareholders (LSHO) & & & 0.0044 & 0.31 \\
\hline Free cash flow (FCF) & 0.35684 & 0.75 & 0.3028 & 0.65 \\
\hline $\ln ($ Market capitalization (MC)in U.S. \$ ) & 0.08702 & 0.66 & 0.0488 & 0.36 \\
\hline Growth rate (GROW) & 0.01346 & 0.36 & 0.0051 & 0.14 \\
\hline Firm leverage (LEV) & -0.00667 & -2.52 & -0.0065 & -2.53 \\
\hline Bus ines s risk (BETA) & 0.45336 & 1.39 & 0.4789 & 1.45 \\
\hline Firm profitability (PROF) & 0.03309 & 3.23 & 0.0328 & 3.29 \\
\hline Constant & -0.88026 & -0.53 & -0.3372 & -0.2 \\
\hline \multicolumn{5}{|l|}{ Descriptive s tatis tics } \\
\hline Wald statistic & 22.59 & & 26.79 & \\
\hline P-value $>$ W ald statistic & 0.002 & & 0.0015 & \\
\hline Observations & 185 & & 185 & \\
\hline Panel-level variance(rho) & 0.3408 & & 0.6553 & \\
\hline log-likelihood at convergence & -94.34 & & -91.47 & \\
\hline
\end{tabular}

